\title{
Sex differences in monocytes and TLR4 associated immune responses; implications for systemic lupus erythematosus (SLE)
}

\author{
Wei Jiang ${ }^{1 *}$ and Gary Gilkeson ${ }^{2}$ \\ *Correspondence: jianw@musc.edu

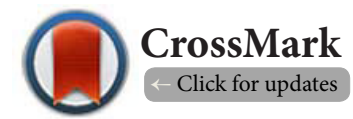 \\ 'Department of Microbiology and Immunology, Division of Infectious Diseases, Department of Medicine, Medical University of South \\ Carolina, USA. \\ ${ }^{2}$ Division of Rheumatology, Department of Medicine, Medical University of South Carolina, USA.
}

\begin{abstract}
It has been shown that TLR7 and TLR9 signaling play a role in SLE pathogenesis. Our recent study revealed that estrogen receptor a knockout mice have impaired inflammatory responses to TLR3, TLR4, TLR7 and TLR9 ligand stimulation in DCs, B cells and whole spleen cells. These findings indicate that estrogen receptor mediated signaling may impact universal TLR responsiveness. Whether estrogen has a direct or indirect effect on TLR responsiveness by immune cells is not clear. There is evidence of a role of TLR4 in SLE disease pathogenesis, such as the kidney damage, the induction of CD40 and autoantibodies, the suppression of regulatory T cells, and the role of pro-inflammatory cytokines (e.g., IL-6, IL-1 $\beta$, TNF- $\alpha$ ) in SLE pathogenesis that can be induced by TLR4-mediated monocyte activation, suggesting that TLR4 and TLR4 responsiveness are also important for SLE disease. This review will focus on TLR4 responses and monocytes, which are understudied in systemic autoimmune diseases such as SLE.
\end{abstract}

Keywords: Toll-like receptor, monocytes, sex, autoimmunity, SLE

\section{Review}

Women exhibit stronger cellular-mediated and humoralmediated immune responses compared to men, and a higher risk of autoimmune disease [1]. The ratio of female to male disease prevalence of systemic lupus erythematosus (SLE), for example, is 9:1 [2]. Although several mechanisms, such as Tolllike receptor (TLR) 7 expression, activity of T regulatory cells, or genetic and environmental factors [1-10], could account for heightened immune responses and increased incidences of autoimmune disease in women, the exact mechanisms are not fully understood. Though sex chromosomes partially account for the sex differences in autoimmune diseases; sex hormones and their receptors are also a likely major determinantas the onset of SLE most often occurs in women at the age of childbearing potential [11].

In the periphery, human B cells express estrogen receptor $\beta$, while plasmacytoid dendritic cells (pDCs) and CD4 T cells express estrogen receptor a. CD8 T cells and monocytes express low to undetectable levels of estrogen receptors [12] Studies from Guery's group [13] showed that pDCs from premenopausal women have heightened responses to TLRs compared to men, while pDCs from postmenopausal women do not. Adding estrogen in vitro to $\mathrm{pDC}$ cultures had no effect on TLR7 responses. When postmenopausal women were given estrogen replacement, their $\mathrm{pDC}$ shad responses similar to premenopausal women. Again, in vitro addition of estrogen had no effect. These effects were mediated via ERa and were pDC centric, and indicate that the effect of estrogen on TLR responses of $\mathrm{pDCs}$ from women is via an indirect mechanism [13]. Our previous study showed that TLR3, TLR4, TLR7 and TLR9 responsiveness was decreased in immune cells from estrogen receptor a knockout mice [14], suggesting that not only TLR7 responsiveness, but other TLR responsivenessis modified by estrogen receptor signaling. But whether estrogen has a direct effect on TLR responsiveness in peripheral lymphocytes is not clear. Dendritic cells (DCs), especially pDCs produce a large amount of IFN-a in response to TLR7and TLR9 ligands, which play an important role in the pathogenesis of SLE disease $[15,16]$. pDCsproduce more IFN- $\alpha$ in women than men in response to TLR7 ligands, perhaps due to TLR7 being located on the $X$ chromosome leading to variable responsiveness $[\mathbf{8 , 1 7 ]}$. The universal heightened TLR7 responsiveness in women versus men would argue against variable TLR7 expression in individual women being the proximate mechanism. To expand the scope of sex differences in TLR responsiveness beyond TLR7 and dendritic cells, this review will focus on sex differences in TLR4 responsiveness and monocyte populations in healthy individuals and patients with SLE.

\section{Monocytes}

Human monocytes represent $5-10 \%$ of peripheral blood mononuclear cells (PBMCs) and are progenitors of macrophages and DCs [18-20]. They express high levels of TLR1, TLR2 and TLR4 compared to lymphocytes [21], and produce pro-inflammatory cytokines (e.g., IL-6, TNF-a, IL-1 $\beta$ ) triggered through TLR activation [16]. Little is known about the effect of sex hormones 
on the modulation of monocyte activation, maturation, subset differentiation, and antigen-presentation function. Previous studies showed increased total monocyte numbers in the periphery in the luteal phase compared to the follicular phase in women [22]. The data on estrogen receptor expression on monocytes is controversial [12,23-26]. Progesterone and testosterone receptors are not expressed in monocytes.

\section{Monocyte subsets}

Monocytes can be defined into two subsets (CD14+CD16+, CD14+CD16-) or three subsets (CD14++CD16-, CD14++CD16+, CD14+CD16++) as identified recently [27-31]. CD14++CD16classic monocytes produce IL-10; and CD16-expressing non-classic monocytes (either intermediate or non-classical subset) produce TNF- $\alpha$, IL- 6 and IL- $1 \beta$ in response to a variety of TLR ligands [32,33]. The non-classic monocyte subset (CD14+CD16++) expresses a unique pattern of chemokine receptors and produces pro-inflammatory cytokines, and plays a role in cardiovascular risk in chronic kidney disease [31]. Moreover, these cells have distinct effector responses to virus and immune complexes containing nucleic acids, via a TLR7 or TLR8 pathway [29]. Virus and certain pro-inflammatory cytokines (e.g., type I IFN) have the function of regulating the expression of CD16 on monocytes [29,34,35]. Elevated levels of CD16-expressing monocytes are seen in blood during inflammatory conditions, such as HIV disease, atherosclerosis $[27,30,36]$, sepsis [37], rheumatoid arthritis, SLE [38-40], and cancer [41], suggesting that inflammation (including microbial TLR ligands) promotes monocyte differentiation into a CD16expressing subset in vivo. CD16 expression on monocytes can be regulated by estradiol in vitro, but the results are controversial $[42,43]$.

\section{Monocyte activation and maturation}

LPS activates and promotes maturation of monocytes $[44,45]$. After activation and maturation, monocytes increase expression of CD80, CD40, CD86 and HLA-DR, secrete pro-inflammatory cytokines (e.g., TNF- $\alpha$, IL-6, IL-1 $\beta$ and sCD14), and change their ability for phagocytosis and antigen presenting and processing function $[\mathbf{4 4 , 4 5 ]}$. These cells can differentiate to macrophages and DCs under certain conditions [46-48]. DCs are professional antigen presenting cells due to their ability to prime naïve T cells and cross present to CD8 T cells $[49,50]$. On the other hand, monocytes, as another type of antigenpresenting cells, account for $5-10 \%$ of cells in the peripheral blood, compared to $1 \%$ of DCs. Although less ability to present antigens to $T$ cells compared to DCs, monocytes are important in antigen presentation overall due to their large number in the periphery and their roles as DC progenitors.

\section{Monocytes in SLE}

An increased number of monocytes and increased activation of monocytes are present in the periphery in SLE patients compared to controls [51]. Monocytes spontaneously release pro-inflammatory cytokines such as IL- 6 and are a predominant source of IL-6 in SLE [52]. CD16+DR++ monocytes are also the major source of TNFa in response to TLR stimulation [33]. Treatments targeting such pro-inflammatory cytokines (e.g., TNFa, IL- 6 and IL-1 $\beta$ ) are effective in animal models of SLE and patients with SLE [53-56]. These results suggest that monocytes are activated in vivo, produce pro-inflammatory cytokines (e.g., IL-6), and play a key role in chronic inflammation and disease pathogenesis in SLE [57]. Moreover, LPS also may account for kidney damage in SLE disease $[\mathbf{5 8 , 5 9 ]}$. Therefore, there may be a link between TLR4 signaling, LPS-mediated monocyte activation, subset differentiation, and SLE pathogenesis. An elevated plasma level of soluble CD14, which is released by monocytes in response to LPS, is present in SLE patients [60]. Our previous work indicated that TLR9 ligands, bacterial CpG ODNs, induce monocytes to express CD80, CD86, CD40 and HLA-DR, and drive monocytes to be better antigen-presenting cells; this effect is through type I IFN [61]. Moreover, in vitro IFN- $\alpha$ induces monocyte activation as measured by expression of CD80, CD86, CD40 and HLA-DR [61]. Levels of IFN- $a$ are elevated and involved in the pathogenesis of SLE [62]. In vitro, these monocytes have impaired ability to up-regulate CD80

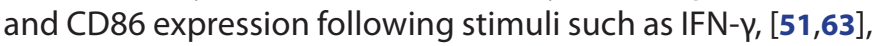
suggesting that in vivo monocytes in SLE are pre-activated. Therefore they may be desensitized to be activated again in vitro. Moreover, Fc gamma receptor genes, associated with monocyte activation, partially account for the underlying immune mechanisms resulting in SLE [64-69]. Patients with SLE have increased levels of pro-inflammatory cytokines in plasma, implying that heightened levels of innate immune responses, including TLR signaling, may contribute to the etiology and pathogenesis in SLE.

\section{TLRs}

TLRs play an important role in innate immunity and recognize pathogens through pathogen associated molecular patterns (PAMPs). In the periphery, antigen-presenting cells (monocytes/ macrophages, DCs and B cells) are the predominant cell populations to express TLRs, and directly respond to TLR ligands $[16,70]$. TLR signals are essensal for maintaining normal immunity, and certain TLR ligands such as CpG ODNs and imiqimod are used as vaccine adjuvants to increase vaccinespecific responses [71,72]. Cytoplasmic Toll-IL-1 receptor (TIR) domains are activated by TLR signaling pathway initially. The TLR-activated TIR domain is associated with MyD88, which recruits IL-1 receptor associated kinase (IRAK) to TLRs upon activation. MyD88 knockout mice have no response to stimulation by TLR5, TLR7 and TLR9 ligands [73-76]. These evidences indicate that the TIR domain-associated adaptor MyD88 is nessessary for these TLR mediated responses [77]. Consistently, responses to TLR2, TLR3, TLR4, and TLR9 agonists are almost abolished in IRAK-4 knockout mice [78]. There are, however, also MyD88-independent TLR signaling pathways [79]. These findings in animal models suggest that TLR signaling 
knockout results in immune-deficiencies, while, robust TLRmediated hyperactivity could drive autoimmune diseases. It is well recognized that females have heightened responses to TLR7 ligands $[8,17]$. Human B cells, pDCs and myeloid dendritic cells ( $\mathrm{mDCs}$ ) express TLR7, and respond to its ligands, imiquimod, HIV viral sequences, gardiquimod or loxoribine et al., [21]. TLR7 signaling is involved in SLE disease largely due to its downstream cytokine IFN-a production by $\mathrm{pDC}$, resulting in higher levels of IFN- $a$ in cells from females compared to males, and in SLE patients compared to controls [17,80-82]. TLR7, TLR8 and TLR9 signaling pathways in pDCs in SLE are extensively studied, and treatment with inhibitors against TLR7/8 and TLR9 are in Phase I trials in patients with SLE [83-86].

\section{TLR4 expression and responsiveness}

In the periphery, human monocytes express the highest TLR4 levelsof PBMCs. MDC sare the other cell type to express TLR4; both cells produce pro-inflammatory cytokines such as IL-1 $\beta$, TNF- $\alpha$ or IL-6 in response to the TLR4 ligand LPS $[21,87,88]$. Human pDCs, B cells, T cells, and NK cells do not express TLR4, and do not directly respond to its ligand LPS [21]. TLR4 knockout or mutationsin mice exhibit defects in responses to LPS, including pro-inflammatory cytokine production, susceptibility to bacterial infections, tissue injury induced ischemia, myocardial infarction, neuro-degeneration, and cancer related immunities [77,89-95].

\section{Sex differences in TLR4 responsiveness in monocytes are listed as follows}

TNF- $\boldsymbol{\alpha}$. Monocytes from males produce higher levels of TNF- $\alpha$ in response to LPS compared to females [96-99]. However, the results from in vitro experiments are conflicting $[96,97,99-102]$. IL-1 $\beta$. There areincreased plasma levels of IL-1 $\beta$ and LPSinduced IL-1 $\beta$-producing monocytes in the luteal phase compared to the follicular phase $[25,103,104]$. IL-12. LPS induced IL-12 production by monocytes was higher in men compared to women, but similar in women in luteal phase versus follicular phase $[\mathbf{2 5}, \mathbf{9 6}]$, suggesting that androgens may affect IL-12 production by monocytes through TLR4. IL-6. Results related to sex differences in IL-6 production in response to LPS in controls and patients with SLE are conflicting [102,105-109]. Aulock's group reported that TNFa, IL-1b, IL-6 and IL-8 production by monocytes in response to LPS was similar or less in women compared to men [99]. Conflicting data were also reported whether estrogen/progesterone affect cytokine production by LPS-stimulated monocytes in humans [96]. The sex differences in monocyte activation and maturation may include both differences in quantity and quality (e.g., genetic factors). It is difficult to draw a conclusion on sex differences in TLR4 responsiveness in monocytes; nevertheless, women seemingly have a reduced TLR4 responsiveness to LPS in monocytes in vitro. This could be due to pre-activation and desensitization in monocytes in women, or due to sex differences in TLR expression and signaling responses in monocytes.

The responses to the TLR4 ligand LPS involve the LPS binding protein (LBP), HDL particles, MD2, TLR4 and soluble CD14 [110-113]. Peripheral LPS is mainly cleared in the liver [114]; LBP transfers LPS to HDL particles, which leads to sequestration of LPS-induced responses $[\mathbf{1 1 2}, \mathbf{1 1 5}]$. A previous study showed that plasma sCD14 also plays a role in the inactivation of LPSinduced host responses [110]. There is no clear evidence of a sex difference in TLR4 expression on monocytes. Although these results were not always consistent, as we stated in the last paragraph, in vivo the levels of several cytokines and in vitro monocyte responses to LPS are different based on female menstrual cycles, suggesting that there is an effect of sex hormones on TLR4 responses and monocytes in vivo. However, it is not clear in vitro whether monocytes have a direct response to estrogen.

Several mechanisms could be accounting for the effect of estrogen on TLR4 effects, including direct effects through levels of estrogen and estrogen receptors, and indirect effects through sex mediated differences in cytokine patterns. TLR4responding cells may express estrogen receptors and directly respond to estrogen. As a result, estrogen activation may change TLR expression or signaling trans duction atthe single cell level. In contrast, TLR-responding cells may not express estrogen receptors. Their response to estrogen is through indirect activation by estrogen-responsive cells. For example, pDCs express ERa and TLR7/TLR9. Estrogen increased TLR7 or TLR9-mediated IFNa production in $\mathrm{PDC}$, but there is no evidence that this is a direct response of pDCs to estrogen [116].

\section{TLR4 responsiveness in SLE}

TLR4 responses play a role in SLE pathogenesis in murine models [117-120]; the potential mechanisms include TLR4mediated suppression of regulatory T cells [121], induction of CD40 expression on antigen-presenting cells [122], and induction of autoantibodies [123]. There is no reported difference in the TLR4 expression in PBMCs from controls and SLE patients [124]. Monocytes spontaneously secrete TNF-a or IL-6 in SLE disease [57]. In vivo, plasma levels of IL-6, IL-10 and TNF- $a$ are elevated in SLE patients compared to controls. Moreover, SLE is associated with increased numbers of monocytes in the periphery, increased expression of Fc receptors, increased levels of IgG production, decreased function of phagocytes in response to LPS, and increased levels of soluble CD14 and LBP [60,125-128]. LPS has a reported pathogenic role in SLE pathogenesis $[58, \mathbf{1 1 7}, \mathbf{1 2 9}]$. In vitro, IL$1 \beta$ and IL- 6 production by monocytes from SLE patients in response to LPS is reduced regardless of disease activity, but TNF-a production remains the same in monocytes compared to controls $[57,130]$. In murine macrophages, TLR4 expression and pro-inflammatory cytokine production are decreased after removal of endogenous estrogens, and exogenous replacement of $17 \beta$-estradiol reverses this effect [131]. Moreover, treatment with low dose steroids or chloroquine 
did not have a significant effect on TLR4 expression and signaling activation. High dose corticosteroids decrease cytokine production (TNF- $\alpha$ and IL-6) in response to LPS $[57,124]$. These results suggest that monocytes from SLE are activated, release pro-inflammatory cytokines, and contribute to disease pathogenesis, especially at target tissue sites (e.g., kidney) $[58,117,129]$.

\section{TLR4 responsiveness and monocyte activation in other} autoimmune diseases

TLR4 responsiveness is reported to play a role in the pathogenesis of other autoimmune diseases besides SLE including coxsackievirus-induced autoimmune myocarditis [132] collagen-induced arthritis [133], primary biliary cirrhosis [134], experimental autoimmune uveitis (EAU) [135], antibodymediated glomerulonephritis [136] and autoimmune destructive arthritis [137]. However, most data were in mice; data in humans are largely lacking. Furthermore, the subset of CD14+/CD16+ blood monocytes is expanded in autoimmune diseases such as rheumatoid arthritis [38], and plays a role in the pathogenesis of experimental autoimmune encephalomyelitis (EAE) [138]. Importantly, TLR4 downstream pro-inflammatory cytokines such as IL-1 $\beta$, TNF- $\alpha$ and IL- 6 are key mediators in several autoimmune diseases [139-142] besides SLE. Therefore, TLR4 signaling is involved in the pathogenesis of several autoimmune diseases, and needs to be studied further.

\section{Genetic predisposition in SLE}

There are variant genes associated with the etiology and pathogenesis of $S L E$, including antigen presentation molecules (HLA-DQ, HLA-DR alleles) $[143,144]$, complement related genes (C1q, C2 and C4) [145-148], Fc gamma receptors (CD64, CD32 and CD16), [64-69], the programmed cell death 1 gene (PDD1) [149-151], IFN and TNF related genes [152-154], and the $C$-reactive protein (CRP) gene $[155,156]$.
Female cells carry both maternal and paternal X chromosomes, whereas male cells carry only the maternal $X$ chromosome. The inactivation of $X$ chromosomes is not random. However, roughly $16 \%$ of healthy females aged 50 or older are shown to have a skewed X-chromosome inactivation $[157,158]$. Furthermore, certain frequencies of $X$-linked genes are known to escape inactivation, and express both alleles on the X-chromosomes [159-161]. It is possible that perturbation in X-chromosome inactivation resultsin the breakdown of tolerance and the induction of autoimmunity.

\section{Anti-estrogen treatment in SLE}

In female (NZB x NZW)F1 and MRLIpr/lpr mice, anti-estrogen had beneficial effects on experimental SLE, including reduction of anti-DNA production and immune complex-mediated glomerulonephritis, and prolonged survival [162-164]. Clearly, estrogen treatment in mice not only enhances disease progression but also drives increased serum anti-dsDNA antibody titers $[162,163,165]$. However, in SLE patients, treatment with anti-estrogens, has led to mixed responses [165-168]. Treatment of female lupus patients with estrogen containing birth control pills premenopausal or use of hormone replacement therapy for post menopausal had minimal to no effect on disease. There is no evidence that use of estrogens increases the risk for developing lupus.

\section{Conclusion}

The subset of CD14+/CD16+ blood monocytes is expanded in sepsis patients, and also elevated in SLE. This subset of monocytes is a major source of pro-inflammatory cytokines such as TNF-a. Data in mice indicate that LPS and TLR4 play a role in mediating autoimmunity, pro-inflammatory cytokine production, and other immune activation. Sexhormones impact TLR4-associated innate immune responses in monocytes in healthy individuals and in patients with SLE (Figure 1). In our model, sex hormones (e.g., estrogen) could directly

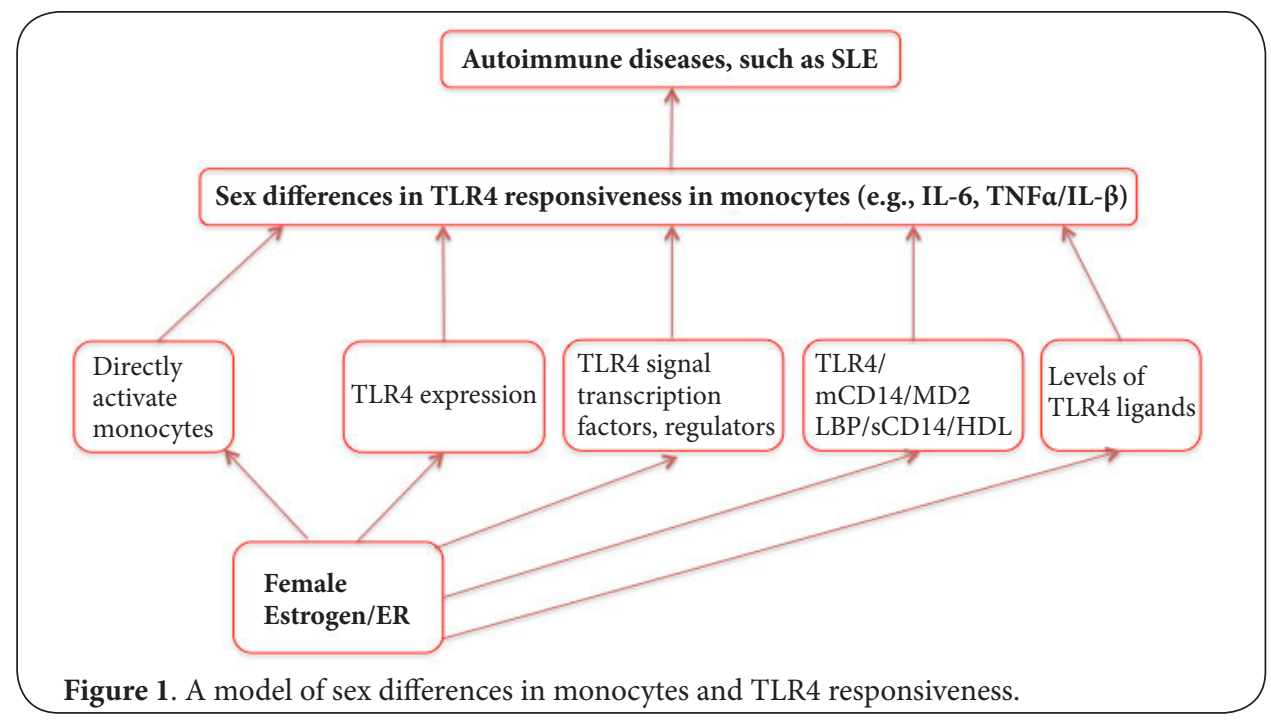


Jiang et al. Journal of Immunotherapy Applications 2014,

activate or indirectly activate monocytes, and change TLR4 responsiveness in monocytes through several mechanisms, such as sex hormone associated changes in the levels of TLR4 ligands, TLR4 expression, TLR4 signaling pathway, and LPS-TLR4 interaction cofactors (Figure 1). Monocytes in SLE patients are activated and produce pro-inflammatory cytokines. Importantly, TLR4-mediated pro-inflammatory cytokines (e.g., IL-6, IL-1 $\beta$ and TNF- $\alpha$ ) are increased and play an important role in the etiology and pathogenesis of SLE [169]. Treatments targeting these cytokines or specificTLRs are atleast partially effective in animal models of SLE and are in clinical trials in patients with SLE $[15,170]$. Therefore, further therapeutic strategies should not only focus on TLR7/8 and TLR9 signaling, but also should investigate the contribution of TLR4 signaling in lupus pathogenesis and sex differences in the prevalence of autoimmune diseases.

\section{List of abbreviations}

TLR: Toll-like receptor TIR: Toll/IL-1 receptor

ERa: Estrogen receptor alpha

SLE: systemic lupus erythematosis

pDCs: plasmacytoid dendritic cells

IFN-a: Interferon alpha

PAMPs: pathogen associated molecular patterns

PBMCs: peripheral blood mononuclear cells

\section{Competing interests}

The authors declare that they have no competing interests.

\section{Authors' contributions}

\begin{tabular}{|l|c|c|}
\hline Authors' contributions & WJ & GG \\
\hline Research concept and design & $\checkmark$ & $\checkmark$ \\
\hline Collection and/or assembly of data & $\checkmark$ & -- \\
\hline Data analysis and interpretation & $\checkmark$ & -- \\
\hline Writing the article & $\checkmark$ & -- \\
\hline Critical revision of the article & -- & $\checkmark$ \\
\hline Final approval of article & $\checkmark$ & $\checkmark$ \\
\hline Statistical analysis & $\checkmark$ & $\checkmark$ \\
\hline
\end{tabular}

\section{Acknowledgement}

This work is supported by NIAID grant AI91526, NIAMS

supplemental grant P60AR062755, the Medical Research Service at the Ralph H. Johnson VAMC, and the National 12th Five-Year Major Projects of China (2012ZX10001-003, 2012ZX10001-006).

\section{Publication history}

Editors: Andrew W. Taylor, Boston University School of Medicine, USA.

Robbie B. Mailliard, University of Pittsburgh, USA.

Received: 17-Aug-2013 Revised: 14-Feb-2014

Accepted: 24-Feb-2014 Published: 07-Mar-2014

\section{References}

1. Voskuhl R. Sex differences in autoimmune diseases. Biol Sex Differ. 2011; 2:1. | Article | PubMed Abstract | PubMed Full Text

2. Weckerle $\mathrm{CE}$ and Niewold TB. The unexplained female predominance of systemic lupus erythematosus: clues from genetic and cytokine studies. Clin Rev Allergy Immunol. 2011; 40:42-9. | Article | PubMed Abstract I PubMed Full Text

3. Afshan G, Afzal N and Qureshi S. CD4+CD25(hi) regulatory T cells in healthy males and females mediate gender difference in the prevalence of autoimmune diseases. Clin Lab. 2012; 58:567-71. | PubMed

4. Klein SL. Immune cells have sex and so should journal articles. Endocrinology. 2012; 153:2544-50. | Article | PubMed Abstract | PubMed Full Text

5. Liu X, Karnell JL, Yin B, Zhang R, Zhang J, Li P, Choi Y, Maltzman JS, Pear WS, Bassing $\mathrm{CH}$ and Turka LA. Distinct roles for PTEN in prevention of T cell lymphoma and autoimmunity in mice. J Clin Invest. 2010; 120:2497-507. | Article | PubMed Abstract | PubMed Full Text

6. Liu Y, Helms C, Liao W, Zaba LC, Duan S, Gardner J, Wise C, Miner A, Malloy MJ, Pullinger CR, Kane JP, Saccone S, Worthington J, Bruce I, Kwok PY, Menter A, Krueger J, Barton A, Saccone NL and Bowcock AM. A genome-wide association study of psoriasis and psoriatic arthritis identifies new disease loci. PLoS Genet. 2008; 4:e1000041. | Article | PubMed Abstract | PubMed Full Text

7. Lorenzo N, Barbera A, Dominguez MC, Torres AM, Hernandez MV, Hernandez I, Gil R, Ancizar J, Garay H, Reyes O, Altruda F, Silengo $L$ and Padron $G$. Therapeutic effect of an altered peptide ligand derived from heat-shock protein 60 by suppressing of inflammatory cytokines secretion in two animal models of rheumatoid arthritis. Autoimmunity. 2012; 45:449-59. | Article | PubMed

8. Meier A, Chang JJ, Chan ES, Pollard RB, Sidhu HK, Kulkarni S, Wen TF, Lindsay RJ, Orellana L, Mildvan D, Bazner S, Streeck H, Alter G, Lifson JD, Carrington M, Bosch RJ, Robbins GK and Altfeld M. Sex differences in the Toll-like receptor-mediated response of plasmacytoid dendritic cells to HIV-1. Nat Med. 2009; 15:955-9. | Article | PubMed Abstract | PubMed Full Text

9. Weckerle CE, Franek BS, Kelly JA, Kumabe M, Mikolaitis RA, Green SL, Utset TO, Jolly M, James JA, Harley JB and Niewold TB. Network analysis of associations between serum interferon-alpha activity, autoantibodies, and clinical features in systemic lupus erythematosus. Arthritis Rheum. 2011; 63:1044-53. | Article | PubMed Abstract | PubMed Full Text

10. Liu Y, Yu Y, Matarese $G$ and La Cava A. Cutting edge: fasting-induced hypoleptinemia expands functional regulatory $\mathrm{T}$ cells in systemic lupus erythematosus. J Immunol. 2012; 188:2070-3. | Article | PubMed Abstract | PubMed Full Text

11. Petri $M$ and Robinson $C$. Oral contraceptives and systemic lupus erythematosus. Arthritis Rheum. 1997; 40:797-803. | Article | PubMed

12. Phiel KL, Henderson RA, Adelman SJ and Elloso MM. Differential estrogen receptor gene expression in human peripheral blood mononuclear cell populations. Immunol Lett. 2005; 97:107-13. | Article I PubMed

13. Seillet C, Rouquie N, Foulon E, Douin-Echinard V, Krust A, Chambon P, Arnal JF, Guery JC and Laffont S. Estradiol promotes functional responses in inflammatory and steady-state dendritic cells through differential requirement for activation function-1 of estrogen receptor alpha. J Immunol. 2013; 190:5459-70. | Article | PubMed

14. Cunningham MA, Naga OS, Eudaly JG, Scott JL and Gilkeson GS. Estrogen receptor alpha modulates Toll-like receptor signaling in murine lupus. Clin Immunol. 2012; 144:1-12. | Article | PubMed Abstract | PubMed Full Text

15. Merrill JT, Wallace DJ, Petri M, Kirou KA, Yao Y, White WI, Robbie G, Levin R, Berney SM, Chindalore V, Olsen N, Richman L, Le C, Jallal B and White B. Safety profile and clinical activity of sifalimumab, a fully human anti-interferon alpha monoclonal antibody, in systemic lupus erythematosus: a phase I, multicentre, double-blind randomised study. Ann Rheum Dis. 2011; 70:1905-13. | Article | PubMed

16. Krieg $A M$ and Vollmer J. Toll-like receptors 7, 8, and 9: linking innate immunity to autoimmunity. Immunol Rev. 2007; 220:251-69. | Article I PubMed

17. Berghofer B, Frommer T, Haley G, Fink L, Bein G and Hackstein H. TLR7 
ligands induce higher IFN-alpha production in females. J Immunol. 2006; 177:2088-96. | Article | PubMed

18. Chomarat P, Dantin C, Bennett L, Banchereau J and Palucka AK. TNF skews monocyte differentiation from macrophages to dendritic cells. J Immunol. 2003; 171:2262-9. | Article | PubMed

19. Auffray C, Fogg DK, Narni-Mancinelli E, Senechal B, Trouillet C, Saederup N, Leemput J, Bigot K, Campisi L, Abitbol M, Molina T, Charo I, Hume DA, Cumano A, Lauvau G and Geissmann F. CX3CR1+ CD115+ CD135+ common macrophage/DC precursors and the role of CX3CR1 in their response to inflammation. J Exp Med. 2009; 206:595-606. | Article | PubMed Abstract | PubMed Full Text

20. Ginhoux F, Tacke F, Angeli V, Bogunovic M, Loubeau M, Dai XM, Stanley $E R$, Randolph GJ and Merad M. Langerhans cells arise from monocytes in vivo. Nat Immunol. 2006; 7:265-73. | Article | PubMed

21. Hornung V, Rothenfusser S, Britsch S, Krug A, Jahrsdorfer B, Giese $T$, Endres $S$ and Hartmann G. Quantitative expression of toll-like receptor 1-10 mRNA in cellular subsets of human peripheral blood mononuclear cells and sensitivity to $\mathrm{CpG}$ oligodeoxynucleotides. J Immunol. 2002; 168:4531-7. | Article | PubMed

22. Mathur S, Mathur RS, Goust JM, Williamson $\mathrm{HO}$ and Fudenberg HH. Cyclic variations in white cell subpopulations in the human menstrual cycle: correlations with progesterone and estradiol. Clin Immunol Immunopathol. 1979; 13:246-53. | Article | PubMed

23. Suenaga R, Evans MJ, Mitamura K, Rider V and Abdou NI. Peripheral blood $T$ cells and monocytes and $B$ cell lines derived from patients with lupus express estrogen receptor transcripts similar to those of normal cells. J Rheumatol. 1998; 25:1305-12. | Article | PubMed

24. Wada K, Itoh T, Nakagawa M, Misao R, Mori H and Tamaya T. Estrogen binding sites in peripheral blood monocytes and effects of danazol on their sites in vitro. Gen Pharmacol. 1992; 23:693-700. | Article | PubMed

25. Bouman A, Moes $H$, Heineman MJ, de Leij LF and Faas MM. The immune response during the luteal phase of the ovarian cycle: increasing sensitivity of human monocytes to endotoxin. Fertil Steril. 2001; 76:555-9. | Article | PubMed

26. McCrohon JA, Nakhla S, Jessup W, Stanley KK and Celermajer DS. Estrogen and progesterone reduce lipid accumulation in human monocyte-derived macrophages: a sex-specific effect. Circulation. 1999; 100:2319-25. | Article | PubMed

27. Aguilar-Ruiz SR, Torres-Aguilar H, Gonzalez-Dominguez E, Narvaez J, Gonzalez-Perez G, Vargas-Ayala G, Meraz-Rios MA, Garcia-Zepeda EA and Sanchez-Torres C. Human CD16+ and CD16- monocyte subsets display unique effector properties in inflammatory conditions in vivo. J Leukoc Biol. 2011; 90:1119-31. | Article | PubMed

28. Amir O, Spivak I, Lavi I and Rahat MA. Changes in the monocytic subsets CD14(dim)CD16(+) and CD14(++)CD16(-) in chronic systolic heart failure patients. Mediators Inflamm. 2012; 2012:616384. | Article | PubMed Abstract | PubMed Full Text

29. Cros J, Cagnard N, Woollard K, Patey N, Zhang SY, Senechal B, Puel A, Biswas SK, Moshous D, Picard C, Jais JP, D'Cruz D, Casanova JL, Trouillet $C$ and Geissmann F. Human CD14dim monocytes patrol and sense nucleic acids and viruses via TLR7 and TLR8 receptors. Immunity. 2010; 33:375-86. | Article | PubMed Abstract | PubMed Full Text

30. Funderburg NT, Zidar DA, Shive C, Lioi A, Mudd J, Musselwhite LW, Simon DI, Costa MA, Rodriguez B, Sieg SF and Lederman MM. Shared monocyte subset phenotypes in HIV-1 infection and in uninfected subjects with acute coronary syndrome. Blood. 2012; 120:4599-608. I Article | PubMed Abstract | PubMed Full Text

31. Heine GH, Ortiz A, Massy ZA, Lindholm B, Wiecek A, Martinez-Castelao A, Covic A, Goldsmith D, Suleymanlar G, London GM, Parati G, Sicari R, Zoccali $C$ and Fliser D. Monocyte subpopulations and cardiovascular risk in chronic kidney disease. Nat Rev Nephrol. 2012; 8:362-9. | Article I PubMed

32. Rossol M, Kraus S, Pierer M, Baerwald $C$ and Wagner $U$. The CD14(bright) CD16+ monocyte subset is expanded in rheumatoid arthritis and promotes expansion of the Th17 cell population. Arthritis Rheum. 2012; 64:671-7. | Article | PubMed
33. Belge KU, Dayyani F, Horelt A, Siedlar M, Frankenberger M, Frankenberger B, Espevik T and Ziegler-Heitbrock L. The proinflammatory CD14+CD16+DR++ monocytes are a major source of TNF. J Immunol. 2002; 168:3536-42. | Article | PubMed

34. Liaskou E, Zimmermann HW, Li KK, Oo YH, Suresh S, Stamataki Z, Qureshi O, Lalor PF, Shaw J, Syn WK, Curbishley SM and Adams DH. Monocyte subsets in human liver disease show distinct phenotypic and functional characteristics. Hepatology. 2013; 57:385-98. | Article I PubMed

35. Wong KL, Tai JJ, Wong WC, Han H, Sem X, Yeap WH, Kourilsky P and Wong SC. Gene expression profiling reveals the defining features of the classical, intermediate, and nonclassical human monocyte subsets. Blood. 2011; 118:e16-31. | Article | PubMed

36. Schlitt A, Heine GH, Blankenberg S, Espinola-Klein C, Dopheide JF, Bickel C, Lackner KJ, Iz M, Meyer J, Darius H and Rupprecht HJ. CD14+CD16+ monocytes in coronary artery disease and their relationship to serum TNF-alpha levels. Thromb Haemost. 2004; 92:419-24. | Article | PubMed

37. Fingerle G, Pforte A, Passlick B, Blumenstein $M$, Strobel $M$ and ZieglerHeitbrock HW. The novel subset of CD14+/CD16+ blood monocytes is expanded in sepsis patients. Blood. 1993; 82:3170-6. | Article | PubMed

38. Cairns AP, Crockard AD and Bell AL. The CD14+ CD16+ monocyte subset in rheumatoid arthritis and systemic lupus erythematosus. Rheumatol Int. 2002; 21:189-92. | Article | PubMed

39. Nakatani K, Yoshimoto S, Iwano M, Asai O, Samejima K, Sakan H, Terada $M$, Hasegawa $H$, Nose $M$ and Saito $Y$. Fractalkine expression and CD16+ monocyte accumulation in glomerular lesions: association with their severity and diversity in lupus models. Am J Physiol Renal Physiol. 2010; 299:F207-16. | Article | PubMed

40. Yoshimoto S, Nakatani K, Iwano M, Asai O, Samejima K, Sakan H, Terada M, Harada K, Akai Y, Shiiki H, Nose M and Saito Y. Elevated levels of fractalkine expression and accumulation of CD16+ monocytes in glomeruli of active lupus nephritis. Am J Kidney Dis. 2007; 50:47-58. | Article I PubMed

41. Saleh MN, Goldman SJ, LoBuglio AF, Beall AC, Sabio H, McCord MC, Minasian L, Alpaugh RK, Weiner LM and Munn DH. CD16+ monocytes in patients with cancer: spontaneous elevation and pharmacologic induction by recombinant human macrophage colony-stimulating factor. Blood. 1995; 85:2910-7. | Article | PubMed

42. Kramer PR, Winger V and Kramer SF. 17beta-Estradiol utilizes the estrogen receptor to regulate CD16 expression in monocytes. Mol Cell Endocrinol. 2007; 279:16-25. | Article | PubMed Abstract | PubMed Full Text

43. Kramer PR, Kramer SF and Guan G. $\mathbf{1 7}$ beta-estradiol regulates cytokine release through modulation of CD16 expression in monocytes and monocyte-derived macrophages. Arthritis Rheum. 2004; 50:1967-75. | Article | PubMed

44. Guha M, O'Connell MA, Pawlinski R, Hollis A, McGovern P, Yan SF, Stern $D$ and Mackman N. Lipopolysaccharide activation of the MEK-ERK1/2 pathway in human monocytic cells mediates tissue factor and tumor necrosis factor alpha expression by inducing Elk-1 phosphorylation and Egr-1 expression. Blood. 2001; 98:1429-39. | Article | PubMed

45. Rossol M, Heine $H$, Meusch $U$, Quandt D, Klein C, Sweet MJ and Hauschildt S. LPS-induced cytokine production in human monocytes and macrophages. Crit Rev Immunol. 2011; 31:379-446. | Article | PubMed

46. Iwamoto S, Iwai S, Tsujiyama K, Kurahashi C, Takeshita K, Naoe M, Masunaga A, Ogawa $Y$, Oguchi $K$ and Miyazaki A. TNF-alpha drives human CD14+ monocytes to differentiate into CD70+ dendritic cells evoking Th1 and Th17 responses. J Immunol. 2007; 179:1449-57. | Article | PubMed

47. Polancec DS, Munic Kos V, Banjanac M, Vrancic M, Cuzic S, Belamaric D, Parnham MJ, Polancec D and Erakovic Haber V. Azithromycin drives in vitro GM-CSF/IL-4-induced differentiation of human blood monocytes toward dendritic-like cells with regulatory properties. J Leukoc Biol. 2012; 91:229-43. | Article | PubMed 
Jiang et al. Journal of Immunotherapy Applications 2014,

48. Auffray C, Sieweke MH and Geissmann F. Blood monocytes: development, heterogeneity, and relationship with dendritic cells. Annu Rev Immunol. 2009; 27:669-92. | Article | PubMed

49. Ji $Q$, Castelli $L$ and Goverman JM. MHC class I-restricted myelin epitopes are cross-presented by Tip-DCs that promote determinant spreading to CD8(+) T cells. Nat Immunol. 2013; 14:254-61. | Article | PubMed Abstract | PubMed Full Text

50. Mouries J, Moron G, Schlecht G, Escriou N, Dadaglio G and Leclerc C. Plasmacytoid dendritic cells efficiently cross-prime naive $T$ cells in vivo after TLR activation. Blood. 2008; 112:3713-22. | Article | PubMed Abstract | PubMed Full Text

51. Liu MF, Li JS, Weng TH and Lei HY. Differential expression and modulation of costimulatory molecules CD80 and CD86 on monocytes from patients with systemic lupus erythematosus. Scand J Immunol. 1999; 49:82-7. | Article | PubMed

52. Mellor-Pita S, Citores MJ, Castejon R, Yebra-Bango M, Tutor-Ureta P, Rosado S, Andreu JL and Vargas JA. Monocytes and T lymphocytes contribute to a predominance of interleukin 6 and interleukin 10 in systemic lupus erythematosus. Cytometry B Clin Cytom. 2009; 76:26170. | Article | PubMed

53. Aringer $\mathrm{M}$ and Smolen JS. The role of tumor necrosis factor-alpha in systemic lupus erythematosus. Arthritis Res Ther. 2008; 10:202 . I Article | PubMed Abstract | PubMed Full Text

54. Liang B, Gardner DB, Griswold DE, Bugelski PJ and Song XY. Antiinterleukin- 6 monoclonal antibody inhibits autoimmune responses in a murine model of systemic lupus erythematosus. Immunology. 2006; 119:296-305. | Article | PubMed Abstract | PubMed Full Text

55. Mihara $\mathrm{M}$, Takagi $\mathrm{N}$, Takeda $\mathrm{Y}$ and Ohsugi $\mathrm{Y}$. IL- 6 receptor blockage inhibits the onset of autoimmune kidney disease in NZB/W F1 mice. Clin Exp Immunol. 1998; 112:397-402. | Article | PubMed Abstract | PubMed Full Text

56. Robak E and Robak T. Monoclonal antibodies in the treatment of systemic lupus erythematosus. Curr Drug Targets. 2009; 10:26-37. | Article | PubMed

57. Swaak AJ, van den Brink HG and Aarden LA. Cytokine production (IL-6 and TNF alpha) in whole blood cell cultures of patients with systemic lupus erythematosus. Scand J Rheumatol. 1996; 25:233-8. | PubMed

58. Zhai JX, Zhang ZX, Feng YJ, Ding SS, Wang XH, Zou LW and Ye DQ. PDTC attenuate LPS-induced kidney injury in systemic lupus erythematosusprone MRL/Ipr mice. Mol Biol Rep. 2012; 39:6763-71. | Article | PubMed

59. Zhang Y, Liu S, Yu Y, Zhang T, Liu J, Shen $Q$ and Cao X. Immune complex enhances tolerogenecity of immature dendritic cells via FcgammaRIlb and promotes FcgammaRIlb-overexpressing dendritic cells to attenuate lupus. Eur J Immunol. 2011; 41:1154-64. | Article | PubMed

60. Nockher WA, Wigand R, Schoeppe W and Scherberich JE. Elevated levels of soluble CD14 in serum of patients with systemic lupus erythematosus. Clin Exp Immunol. 1994; 96:15-9. | Article | PubMed Abstract | PubMed Full Text

61. Jiang W, Lederman MM, Salkowitz JR, Rodriguez B, Harding CV and Sieg SF. Impaired monocyte maturation in response to $\mathrm{CpG}$ oligodeoxynucleotide is related to viral RNA levels in human immunodeficiency virus disease and is at least partially mediated by deficiencies in alpha/beta interferon responsiveness and production J Virol. 2005; 79:4109-19. | Article | PubMed Abstract | PubMed Full $\underline{\text { Text }}$

62. Lindau D, Mussard J, Rabsteyn A, Ribon M, Kotter I, Igney A, Adema GJ, Boissier MC, Rammensee HG and Decker P. TLR9 independent interferon alpha production by neutrophils on NETosis in response to circulating chromatin, a key lupus autoantigen. Ann Rheum Dis. 2013. | Article | PubMed

63. Tsokos GC, Kovacs B, Sfikakis PP, Theocharis S, Vogelgesang S and Via CS. Defective antigen-presenting cell function in patients with systemic lupus erythematosus. Arthritis Rheum. 1996; 39:600-9. | Article | PubMed

64. Brown EE, Edberg JC and Kimberly RP. Fc receptor genes and the systemic lupus erythematosus diathesis. Autoimmunity. 2007; 40:567-
81. | Article | PubMed

65. Wu J, Edberg JC, Redecha PB, Bansal V, Guyre PM, Coleman K, Salmon JE and Kimberly RP. A novel polymorphism of FcgammaRIIIa (CD16) alters receptor function and predisposes to autoimmune disease. $J$ Clin Invest. 1997; 100:1059-70. | Article | PubMed Abstract | PubMed Full Text

66. Salmon JE, Millard S, Schachter LA, Arnett FC, Ginzler EM, Gourley MF, Ramsey-Goldman R, Peterson MG and Kimberly RP. Fc gamma RIIA alleles are heritable risk factors for lupus nephritis in African Americans. J Clin Invest. 1996; 97:1348-54. | Article | PubMed Abstract I PubMed Full Text

67. Kyogoku C, Dijstelbloem HM, Tsuchiya N, Hatta $Y$, Kato $H$, Yamaguchi A, Fukazawa T, Jansen MD, Hashimoto H, van de Winkel JG, Kallenberg CG and Tokunaga K. Fcgamma receptor gene polymorphisms in Japanese patients with systemic lupus erythematosus: contribution of FCGR2B to genetic susceptibility. Arthritis Rheum. 2002; 46:1242-54. | Article I PubMed

68. Li Y, Lee PY, Sobel ES, Narain S, Satoh M, Segal MS, Reeves WH and Richards HB. Increased expression of FcgammaRI/CD64 on circulating monocytes parallels ongoing inflammation and nephritis in lupus. Arthritis Res Ther. 2009; 11:R6. | Article | PubMed Abstract | PubMed Full Text

69. Karassa FB, Trikalinos TA and loannidis JP. Role of the Fcgamma receptor lla polymorphism in susceptibility to systemic lupus erythematosus and lupus nephritis: a meta-analysis. Arthritis Rheum. 2002; 46:1563-71. | Article | PubMed

70. Barton $\mathrm{GM}$ and Medzhitov R. Toll-like receptor signaling pathways. Science. 2003; 300:1524-5. | Article | PubMed

71. Duthie MS, Windish HP, Fox CB and Reed SG. Use of defined TLR ligands as adjuvants within human vaccines. Immunol Rev. 2011; 239:178-96. | Article | PubMed

72. Kwissa M, Nakaya HI, Oluoch $\mathrm{H}$ and Pulendran B. Distinct TLR adjuvants differentially stimulate systemic and local innate immune responses in nonhuman primates. Blood. 2012; 119:2044-55. | Article | PubMed Abstract | PubMed Full Text

73. Hacker H, Vabulas RM, Takeuchi O, Hoshino K, Akira S and Wagner $\mathrm{H}$. Immune cell activation by bacterial CpG-DNA through myeloid differentiation marker 88 and tumor necrosis factor receptorassociated factor (TRAF)6. J Exp Med. 2000; 192:595-600. | Article | PubMed Abstract | PubMed Full Text

74. Hayashi F, Smith KD, Ozinsky A, Hawn TR, Yi EC, Goodlett DR, Eng JK, Akira $S$, Underhill DM and Aderem $A$. The innate immune response to bacterial flagellin is mediated by Toll-like receptor 5 . Nature. 2001; 410:1099-103. | Article | PubMed

75. Hemmi H, Kaisho T, Takeuchi O, Sato S, Sanjo H, Hoshino K, Horiuchi T, Tomizawa $\mathrm{H}$, Takeda $\mathrm{K}$ and Akira S. Small anti-viral compounds activate immune cells via the TLR7 MyD88-dependent signaling pathway. Nat Immunol. 2002; 3:196-200. | Article | PubMed

76. Schnare M, Holt AC, Takeda K, Akira S and Medzhitov R. Recognition of CpG DNA is mediated by signaling pathways dependent on the adaptor protein MyD88. Curr Biol. 2000; 10:1139-42. | Article | PubMed

77. Bauerfeld CP, Rastogi R, Pirockinaite G, Lee I, Huttemann M, Monks B, Birnbaum MJ, Franchi L, Nunez G and Samavati L. TLR4-mediated AKT activation is MyD88/TRIF dependent and critical for induction of oxidative phosphorylation and mitochondrial transcription factor A in murine macrophages. J Immunol. 2012; 188:2847-57. | Article | PubMed Abstract | PubMed Full Text

78. Suzuki N, Suzuki S, Duncan GS, Millar DG, Wada T, Mirtsos C, Takada H, Wakeham A, Itie A, Li S, Penninger JM, Wesche H, Ohashi PS, Mak TW and Yeh WC. Severe impairment of interleukin-1 and Toll-like receptor signalling in mice lacking IRAK-4. Nature. 2002; 416:750-6. | Article | PubMed

79. Kawai T and Akira S. TLR signaling. Cell Death Differ. 2006; 13:816-25. | Article | PubMed

80. Anders $\mathrm{HJ}$, Krug A and Pawar RD. Molecular mimicry in innate immunity? The viral RNA recognition receptor TLR7 accelerates 
Jiang et al. Journal of Immunotherapy Applications 2014,

http://www.hoajonline.com/journals/pdf/2055-2394-1-1.pdf

doi: 10.7243/2055-2394-1-1

murine lupus. Eur J Immunol. 2008; 38:1795-9. | Article | PubMed

81. Pan ZJ, Maier S, Schwarz K, Azbill J, Akira S, Uematsu S and Farris AD. Toll-like receptor 7 (TLR7) modulates anti-nucleosomal autoantibody isotype and renal complement deposition in mice exposed to syngeneic late apoptotic cells. Ann Rheum Dis. 2010; 69:1195-9. Article | PubMed Abstract | PubMed Full Text

82. Pisitkun $P$, Deane JA, Difilippantonio MJ, Tarasenko T, Satterthwaite AB and Bolland S. Autoreactive B cell responses to RNA-related antigens due to TLR7 gene duplication. Science. 2006; 312:1669-72. | Article | PubMed

83. Barrat FJ, Meeker T, Chan JH, Guiducci C and Coffman RL. Treatment of lupus-prone mice with a dual inhibitor of TLR7 and TLR9 leads to reduction of autoantibody production and amelioration of disease symptoms. Eur J Immunol. 2007; 37:3582-6. | Article | PubMed

84. Guiducci C, Gong M, Xu Z, Gill M, Chaussabel D, Meeker T, Chan JH, Wright T, Punaro M, Bolland S, Soumelis V, Banchereau J, Coffman RL, Pascual $V$ and Barrat FJ. TLR recognition of self nucleic acids hampers glucocorticoid activity in lupus. Nature. 2010; 465:937-41. | Article | PubMed Abstract | PubMed Full Text

85. Hennessy EJ, Parker AE and O'Neill LA. Targeting Toll-like receptors: emerging therapeutics? Nat Rev Drug Discov. 2010; 9:293-307. | Article I PubMed

86. Lenert PS. Classification, mechanisms of action, and therapeutic applications of inhibitory oligonucleotides for Toll-like receptors (TLR) 7 and 9. Mediators Inflamm. 2010; 2010:986596. | Article | PubMed Abstract | PubMed Full Text

87. Andersson LI, Hellman P and Eriksson H. Receptor-mediated endocytosis of particles by peripheral dendritic cells. Hum Immunol. 2008; 69:625-33. | Article | PubMed

88. Pelletier S, Bedard N, Said E, Ancuta P, Bruneau J and Shoukry NH. Sustained hyperresponsiveness of dendritic cells is associated with spontaneous resolution of acute hepatitis C. J Virol. 2013; 87:6769-81. | Article | PubMed Abstract | PubMed Full Text

89. Hoshino K, Takeuchi O, Kawai T, Sanjo H, Ogawa T, Takeda Y, Takeda K and Akira S. Cutting edge: Toll-like receptor 4 (TLR4)-deficient mice are hyporesponsive to lipopolysaccharide: evidence for TLR4 as the Lps gene product. J Immunol. 1999; 162:3749-52. | Article | PubMed

90. Illario M, Giardino-Torchia ML, Sankar U, Ribar TJ, Galgani M, Vitiello L, Masci AM, Bertani FR, Ciaglia E, Astone D, Maulucci G, Cavallo A, Vitale M, Cimini V, Pastore L, Means AR, Rossi G and Racioppi L. Calmodulindependent kinase IV links Toll-like receptor 4 signaling with survival pathway of activated dendritic cells. Blood. 2008; 111:723-31. | Article | PubMed Abstract | PubMed Full Text

91. Milanski M, Arruda AP, Coope A, Ignacio-Souza LM, Nunez CE, Roman EA, Romanatto T, Pascoal LB, Caricilli AM, Torsoni MA, Prada PO, Saad $\mathrm{MJ}$ and Velloso LA. Inhibition of hypothalamic inflammation reverses diet-induced insulin resistance in the liver. Diabetes. 2012; 61:145562. | Article | PubMed Abstract | PubMed Full Text

92. Nunez NG, Andreani V, Crespo MI, Nocera DA, Breser ML, Moron G, Dejager L, Libert C, Rivero V and Maccioni M. IFNbeta produced by TLR4-activated tumor cells is involved in improving the antitumoral immune response. Cancer Res. 2012; 72:592-603. | Article | PubMed

93. Riddell JR, Bshara W, Moser MT, Spernyak JA, Foster BA and Gollnick SO. Peroxiredoxin 1 controls prostate cancer growth through Toll-like receptor 4-dependent regulation of tumor vasculature. Cancer Res. 2011; 71:1637-46. | Article | PubMed Abstract | PubMed Full Text

94. Stefanova N, Fellner L, Reindl M, Masliah E, Poewe W and Wenning GK. Toll-like receptor 4 promotes alpha-synuclein clearance and survival of nigral dopaminergic neurons. Am J Pathol. 2011; 179:954-63. | Article | PubMed Abstract | PubMed Full Text

95. Zhuang L, Jung JY, Wang EW, Houlihan P, Ramos L, Pashia M and Chole RA. Pseudomonas aeruginosa lipopolysaccharide induces osteoclastogenesis through a toll-like receptor 4 mediated pathway in vitro and in vivo. Laryngoscope. 2007; 117:841-7. | Article | PubMed

96. Bouman A, Schipper M, Heineman MJ and Faas MM. Gender difference in the non-specific and specific immune response in humans. Am J Reprod Immunol. 2004; 52:19-26. | Article | PubMed
97. Asai K, Hiki N, Mimura Y, Ogawa T, Unou K and Kaminishi M. Gender differences in cytokine secretion by human peripheral blood mononuclear cells: role of estrogen in modulating LPS-induced cytokine secretion in an ex vivo septic model. Shock. 2001; 16:340-3. I Article | PubMed

98. Schwarz E, Schafer C, Bode JC and Bode C. Influence of the menstrual cycle on the LPS-induced cytokine response of monocytes. Cytokine. 2000; 12:413-6. | Article | PubMed

99. Aulock SV, Deininger S, Draing C, Gueinzius K, Dehus O and Hermann C. Gender difference in cytokine secretion on immune stimulation with LPS and LTA. J Interferon Cytokine Res. 2006; 26:887-92. | Article | PubMed

100. Rogers $A$ and Eastell R. The effect of 17 beta-estradiol on production of cytokines in cultures of peripheral blood. Bone. 2001; 29:30-4. I Article | PubMed

101. Ralston SH, Russell RG and Gowen M. Estrogen inhibits release of tumor necrosis factor from peripheral blood mononuclear cells in postmenopausal women. J Bone Miner Res. 1990; 5:983-8. | Article | PubMed

102. Brannstrom M, Friden BE, Jasper M and Norman RJ. Variations in peripheral blood levels of immunoreactive tumor necrosis factor alpha (TNFalpha) throughout the menstrual cycle and secretion of TNFalpha from the human corpus luteum. Eur J Obstet Gynecol Reprod Biol. 1999; 83:213-7. | Article | PubMed

103. Cannon JG and Dinarello CA. Increased plasma interleukin-1 activity in women after ovulation. Science. 1985; 227:1247-9. | Article | PubMed

104. Polan ML, Loukides JA and Honig J. Interleukin-1 in human ovarian cells and in peripheral blood monocytes increases during the luteal phase: evidence for a midcycle surge in the human. Am J Obstet Gynecol. 1994; 170:1000-6. | Article | PubMed

105. Jilma B, Dirnberger E, Loscher I, Rumplmayr A, Hildebrandt J, Eichler HG, Kapiotis $S$ and Wagner OF. Menstrual cycle-associated changes in blood levels of interleukin-6, alpha1 acid glycoprotein, and C-reactive protein. J Lab Clin Med. 1997; 130:69-75. | Article I PubMed

106. Kania DM, Binkley N, Checovich M, Havighurst T, Schilling M and Ershler WB. Elevated plasma levels of interleukin- 6 in postmenopausal women do not correlate with bone density. J Am Geriatr Soc. 1995; 43:236-9. | Article | PubMed

107. McKane WR, Khosla S, Peterson JM, Egan K and Riggs BL. Circulating levels of cytokines that modulate bone resorption: effects of age and menopause in women. J Bone Miner Res. 1994; 9:1313-8. | Article | PubMed

108. Rachon D, Mysliwska J, Suchecka-Rachon K, Wieckiewicz J and Mysliwski A. Effects of oestrogen deprivation on interleukin- 6 production by peripheral blood mononuclear cells of postmenopausal women. J Endocrinol. 2002; 172:387-95. | Article | PubMed

109. Scuderi F, Convertino R, Molino N, Provenzano C, Marino M, Zoli A and Bartoccioni E. Effect of pro-inflammatory/anti-inflammatory agents on cytokine secretion by peripheral blood mononuclear cells in rheumatoid arthritis and systemic lupus erythematosus. Autoimmunity. 2003; 36:71-7. | Article | PubMed

110. Kitchens RL, Thompson PA, Viriyakosol S, O'Keefe GE and Munford RS. Plasma CD14 decreases monocyte responses to LPS by transferring cell-bound LPS to plasma lipoproteins. J Clin Invest. 2001; 108:485-93. | Article | PubMed Abstract | PubMed Full Text

111. Viriyakosol S, Tobias PS, Kitchens RL and Kirkland TN. MD-2 binds to bacterial lipopolysaccharide. J Biol Chem. 2001; 276:38044-51. | Article | PubMed

112. Wurfel MM, Kunitake ST, Lichenstein H, Kane JP and Wright SD. Lipopolysaccharide (LPS)-binding protein is carried on lipoproteins and acts as a cofactor in the neutralization of LPS. J Exp Med. 1994; 180:1025-35. | Article | PubMed Abstract | PubMed Full Text

113. Kitchens RL, Wolfbauer G, Albers JJ and Munford RS. Plasma lipoproteins promote the release of bacterial lipopolysaccharide from the monocyte cell surface. J Biol Chem. 1999; 274:34116-22. | Article I PubMed

114. Coulthard MG, Swindle J, Munford RS, Gerard RD and Meidell RS. 
Jiang et al. Journal of Immunotherapy Applications 2014,

Adenovirus-mediated transfer of a gene encoding acyloxyacyl hydrolase (AOAH) into mice increases tissue and plasma AOAH activity. Infect Immun. 1996; 64:1510-5. | Article | PubMed Abstract | PubMed Full Text

115. Munford RS, Andersen JM and Dietschy JM. Sites of tissue binding and uptake in vivo of bacterial lipopolysaccharide-high density lipoprotein complexes: studies in the rat and squirrel monkey. J Clin Invest. 1981; 68:1503-13. | Article | PubMed Abstract | PubMed Full Text

116. Seillet C, Laffont S, Tremollieres F, Rouquie N, Ribot C, Arnal JF, DouinEchinard V, Gourdy P and Guery JC. The TLR-mediated response of plasmacytoid dendritic cells is positively regulated by estradiol in vivo through cell-intrinsic estrogen receptor alpha signaling. Blood. 2012; 119:454-64. | Article | PubMed

117. Lee TP, Tang SJ, Wu MF, Song YC, Yu CL and Sun KH. Transgenic overexpression of anti-double-stranded DNA autoantibody and activation of Toll-like receptor 4 in mice induce severe systemic lupus erythematosus syndromes. J Autoimmun. 2010; 35:358-67. | Article | PubMed

118. Liu B, Yang Y, Dai J, Medzhitov R, Freudenberg MA, Zhang PL and Li Z. TLR4 up-regulation at protein or gene level is pathogenic for lupuslike autoimmune disease. J Immunol. 2006; 177:6880-8. | Article | PubMed

119. Summers SA, Hoi A, Steinmetz OM, O'Sullivan KM, Ooi JD, Odobasic D, Akira S, Kitching AR and Holdsworth SR. TLR9 and TLR4 are required for the development of autoimmunity and lupus nephritis in pristane nephropathy. J Autoimmun. 2010; 35:291-8. | Article | PubMed

120. Lartigue A, Colliou N, Calbo S, Francois A, Jacquot S, Arnoult C, Tron F, Gilbert D and Musette P. Critical role of TLR2 and TLR4 in autoantibody production and glomerulonephritis in Ipr mutation-induced mouse lupus. J Immunol. 2009; 183:6207-16. | Article | PubMed

121. Dai J, Liu B, Ngoi SM, Sun S, Vella AT and Li Z. TLR4 hyperresponsiveness via cell surface expression of heat shock protein gp96 potentiates suppressive function of regulatory T cells. $J$ Immunol. 2007; 178:3219-25. | Article | PubMed

122. Qin $\mathrm{H}$, Wilson CA, Lee $\mathrm{SJ}$, Zhao $X$ and Benveniste EN. LPS induces CD40 gene expression through the activation of NF-kappaB and STAT-1alpha in macrophages and microglia. Blood. 2005; 106:3114-22. | Article | PubMed Abstract | PubMed Full Text

123. Harlow L, Fernandez I, Soejima M, Ridgway WM and Ascherman DP. Characterization of TLR4-mediated auto-antibody production in a mouse model of histidyl-tRNA synthetase-induced myositis. Innate Immun. 2012; 18:876-85. | Article | PubMed

124. Cepika AM, Bendelja K, Vergles JM, Malenica B, Kapitanovic S and Gagro A. Monocyte response to LPS after exposure to corticosteroids and chloroquine with implications for systemic lupus erythematosus. Scand I Immunol. 2010; 72:434-43. | Article | PubMed

125. Boswell $\mathrm{J}$ and Schur PH. Monocyte function in systemic lupus erythematosus. Clin Immunol Immunopathol. 1989; 52:271-8. | Article I PubMed

126. Carter SD, Bourne JT, Elson CJ, Hutton CW, Czudek R and Dieppe $\mathrm{PA}$. Mononuclear phagocytes in rheumatoid arthritis: Fc-receptor expression by peripheral blood monocytes. Ann Rheum Dis. 1984; 43:424-9. | Article | PubMed Abstract | PubMed Full Text

127. Fries LF, Mullins WW, Cho KR, Plotz PH and Frank MM. Monocyte receptors for the $\mathrm{Fc}$ portion of IgG are increased in systemic lupus erythematosus. J Immunol. 1984; 132:695-700. | Article | PubMed

128. Prokopec KE, Berntson L, Oman A and Kleinau S. Up regulated complement and fc receptors in juvenile idiopathic arthritis and correlation with disease phenotype. J Clin Immunol. 2012; 32:540-50. | Article | PubMed

129. Shui HA, Ka SM, Wu WM, Lin YF, Hou YC, Su LC and Chen A. LPS-evoked IL-18 expression in mesangial cells plays a role in accelerating lupus nephritis. Rheumatology (Oxford). 2007; 46:1277-84. | Article | PubMed

130. Andersen LS, Petersen J, Svenson M and Bendtzen K. Production of IL-1beta, IL-1 receptor antagonist and IL-10 by mononuclear cells from patients with SLE. Autoimmunity. 1999; 30:235-42. | PubMed
131. Rettew JA, Huet YM and Marriott I. Estrogens augment cell surface TLR4 expression on murine macrophages and regulate sepsis susceptibility in vivo. Endocrinology. 2009; 150:3877-84. | Article | PubMed

132. Roberts BJ, Moussawi M and Huber SA. Sex differences in TLR2 and TLR4 expression and their effect on coxsackievirus-induced autoimmune myocarditis. Exp Mol Pathol. 2013; 94:58-64. | Article | PubMed Abstract | PubMed Full Text

133. Park SY, Lee SW, Baek SH, Lee CW, Lee WS, Rhim BY, Hong KW and Kim CD. Suppression of PU.1-linked TLR4 expression by cilostazol with decrease of cytokine production in macrophages from patients with rheumatoid arthritis. Br J Pharmacol. 2013; 168:1401-11. | Article | PubMed

134. Zhao J, Zhao S, Zhou G, Liang L, Guo X, Mao P, Zhou X, Wang H, Nan Y, $\mathrm{Xu} D$ and $Y u$ J. Altered biliary epithelial cell and monocyte responses to lipopolysaccharide as a TLR ligand in patients with primary biliary cirrhosis. Scand J Gastroenterol. 2011; 46:485-94. | Article | PubMed

135. Fang J, Fang D, Silver PB, Wen F, Li B, Ren X, Lin Q, Caspi RR and Su SB. The role of TLR2, TRL3, TRL4, and TRL9 signaling in the pathogenesis of autoimmune disease in a retinal autoimmunity model. Invest Ophthalmol Vis Sci. 2010; 51:3092-9. | Article | PubMed Abstract | PubMed Full Text

136. Brown HJ, Lock HR, Wolfs TG, Buurman WA, Sacks SH and Robson MG Toll-like receptor 4 ligation on intrinsic renal cells contributes to the induction of antibody-mediated glomerulonephritis via CXCL1 and CXCL2. J Am Soc Nephrol. 2007; 18:1732-9. | Article | PubMed

137. Abdollahi-Roodsaz S, Joosten LA, Roelofs MF, Radstake TR, Matera G, Popa C, van der Meer JW, Netea MG and van den Berg WB. Inhibition of Toll-like receptor 4 breaks the inflammatory loop in autoimmune destructive arthritis. Arthritis Rheum. 2007; 56:2957-67. | Article | PubMed

138. Weber MS, Prod'homme T, Youssef S, Dunn SE, Rundle CD, Lee L, Patarroyo JC, Stuve O, Sobel RA, Steinman L and Zamvil SS. Type II monocytes modulate T cell-mediated central nervous system autoimmune disease. Nat Med. 2007; 13:935-43. | Article | PubMed

139. Yang H, Tuzun E, Alagappan D, Yu X, Scott BG, Ischenko A and Christadoss P. IL-1 receptor antagonist-mediated therapeutic effect in murine myasthenia gravis is associated with suppressed serum proinflammatory cytokines, C3, and anti-acetylcholine receptor IgG1. J Immunol. 2005; 175:2018-25. | Article | PubMed

140. Terayama H, Naito M, Qu N, Hirai S, Kitaoka M, Ogawa $Y$ and Itoh M. Intratesticular expression of mRNAs of both interferon gamma and tumor necrosis factor alpha is significantly increased in experimental autoimmune orchitis in mice. J Reprod Dev. 2011; 57:296-302. | Article I PubMed

141. Chen H, Wen F, Zhang $X$ and Su SB. Expression of T-helper-associated cytokines in patients with type 2 diabetes mellitus with retinopathy. Mol Vis. 2012; 18:219-26. | PubMed Abstract | PubMed Full Text

142. Lai WQ, Irwan AW, Goh HH, Howe HS, Yu DT, Valle-Onate R, McInnes IB, Melendez AJ and Leung BP. Anti-inflammatory effects of sphingosine kinase modulation in inflammatory arthritis. J Immunol. 2008; 181:8010-7. | Article | PubMed

143. Harley JB, Sestak AL, Willis LG, Fu SM, Hansen JA and Reichlin M. A model for disease heterogeneity in systemic lupus erythematosus. Relationships between histocompatibility antigens, autoantibodies, and lymphopenia or renal disease. Arthritis Rheum. 1989; 32:826-36. | Article | PubMed

144. Marchini M, Antonioli R, Lleo A, Barili M, Caronni M, Origgi L, Vanoli M and Scorza R. HLA class II antigens associated with lupus nephritis in Italian SLE patients. Hum Immunol. 2003; 64:462-8. | Article | PubMed

145. Agnello V, De Bracco MM and Kunkel HG. Hereditary C2 deficiency with some manifestations of systemic lupus erythematosus. J Immunol. 1972; 108:837-40. | Article | PubMed

146. Nishino $H$, Shibuya K, Nishida $Y$ and Mushimoto M. Lupus erythematosus-like syndrome with selective complete deficiency of C1q. Ann Intern Med. 1981; 95:322-4. | Article | PubMed

147. Pickering MC, Botto M, Taylor PR, Lachmann PJ and Walport MJ. 
Jiang et al. Journal of Immunotherapy Applications 2014,

http://www.hoajonline.com/journals/pdf/2055-2394-1-1.pdf

doi: $10.7243 / 2055-2394-1-1$

Systemic lupus erythematosus, complement deficiency, and apoptosis. Adv Immunol. 2000; 76:227-324. | PubMed

148. Yang Y, Chung EK, Wu YL, Savelli SL, Nagaraja HN, Zhou B, Hebert M, Jones KN, Shu $Y$ and Kitzmiller $K$ et al. Gene copy-number variation and associated polymorphisms of complement component $\mathrm{C} 4$ in human systemic lupus erythematosus (SLE): low copy number is a risk factor for and high copy number is a protective factor against SLE susceptibility in European Americans. Am J Hum Genet. 2007; 80:1037-54. | Article | PubMed Abstract | PubMed Full Text

149. Lin SC, Yen JH, Tsai JJ, Tsai WC, Ou TT, Liu HW and Chen CJ. Association of a programmed death 1 gene polymorphism with the development of rheumatoid arthritis, but not systemic lupus erythematosus. Arthritis Rheum. 2004; 50:770-5. | Article | PubMed

150. Nishimura H, Okazaki T, Tanaka Y, Nakatani K, Hara M, Matsumori A, Sasayama S, Mizoguchi A, Hiai H, Minato N and Honjo T. Autoimmune dilated cardiomyopathy in PD-1 receptor-deficient mice. Science. 2001; 291:319-22. | Article | PubMed

151. Prokunina L, Castillejo-Lopez C, Oberg F, Gunnarsson I, Berg L, Magnusson V, Brookes AJ, Tentler D, Kristjansdottir H, Grondal G, Bolstad Al, Svenungsson E, Lundberg I, Sturfelt G, Jonssen A, Truedsson L, Lima G, Alcocer-Varela J, Jonsson R, Gyllensten UB, Harley JB, Alarcon-Segovia D, Steinsson $\mathrm{K}$ and Alarcon-Riquelme ME. A regulatory polymorphism in PDCD1 is associated with susceptibility to systemic lupus erythematosus in humans. Nat Genet. 2002; 32:666-9. | Article I PubMed

152. Sigurdsson S, Nordmark G, Goring HH, Lindroos K, Wiman AC, Sturfelt G, Jonsen A, Rantapaa-Dahlqvist S, Moller B, Kere J, Koskenmies S, Widen E, Eloranta ML, Julkunen H, Kristjansdottir H, Steinsson K, Alm G, Ronnblom $L$ and Syvanen AC. Polymorphisms in the tyrosine kinase 2 and interferon regulatory factor 5 genes are associated with systemic lupus erythematosus. Am J Hum Genet. 2005; 76:528-37. | Article | PubMed Abstract | PubMed Full Text

153. Taylor KE, Remmers EF, Lee AT, Ortmann WA, Plenge RM, Tian C, Chung SA, Nititham J, Hom G, Kao AH, Demirci FY, Kamboh MI, Petri M, Manzi S, Kastner DL, Seldin MF, Gregersen PK, Behrens TW and Criswell LA. Specificity of the STAT4 genetic association for severe disease manifestations of systemic lupus erythematosus. PLoS Genet. 2008; 4:e1000084. | Article | PubMed Abstract | PubMed Full Text

154. Delgado-Vega AM, Abelson AK, Sanchez E, Witte T, D'Alfonso S, Galeazzi $\mathrm{M}$, Jimenez-Alonso J, Pons-Estel BA, Martin J and Alarcon-Riquelme ME. Replication of the TNFSF4 (OX40L) promoter region association with systemic lupus erythematosus. Genes Immun. 2009; 10:248-53. | Article | PubMed Abstract | PubMed Full Text

155. Stein MP, Edberg JC, Kimberly RP, Mangan EK, Bharadwaj D, Mold C and Du Clos TW. C-reactive protein binding to FcgammaRIla on human monocytes and neutrophils is allele-specific. J Clin Invest. 2000; 105:369-76. | Article | PubMed Abstract | PubMed Full Text

156. Russell Al, Cunninghame Graham DS, Shepherd C, Roberton CA, Whittaker J, Meeks J, Powell RJ, Isenberg DA, Walport MJ and Vyse TJ. Polymorphism at the C-reactive protein locus influences gene expression and predisposes to systemic lupus erythematosus. Hum Mol Genet. 2004; 13:137-47. | Article | PubMed Abstract | PubMed Full Text

157. Sharp A, Robinson D and Jacobs P. Age- and tissue-specific variation of $X$ chromosome inactivation ratios in normal women. Hum Genet. 2000; 107:343-9. | Article | PubMed

158. Chagnon P, Provost S, Belisle C, Bolduc V, Gingras M and Busque L. Ageassociated skewing of $X$-inactivation ratios of blood cells in normal females: a candidate-gene analysis approach. Exp Hematol. 2005; 33:1209-14. | Article | PubMed

159. Brown $\mathrm{CJ}$ and Robinson WP. The causes and consequences of random and non-random X chromosome inactivation in humans. Clin Genet. 2000; 58:353-63. | Article | PubMed

160. Hellman $A$ and Chess A. Gene body-specific methylation on the active X chromosome. Science. 2007; 315:1141-3. | Article | PubMed

161. Carrel $L$ and Willard HF. X-inactivation profile reveals extensive variability in X-linked gene expression in females. Nature. 2005;
434:400-4. | Article | PubMed

162. Sthoeger ZM, Bentwich Z, Zinger $H$ and Mozes E. The beneficial effect of the estrogen antagonist, tamoxifen, on experimental systemic lupus erythematosus. J Rheumatol. 1994; 21:2231-8. | PubMed

163. Sthoeger ZM, Zinger $H$ and Mozes E. Beneficial effects of the antioestrogen tamoxifen on systemic lupus erythematosus of (NZBxNZW) F1 female mice are associated with specific reduction of IgG3 autoantibodies. Ann Rheum Dis. 2003; 62:341-6. | Article | PubMed Abstract I PubMed Full Text

164. Zhang Y, Saha S, Rosenfeld G, Gonzalez J, Pepeljugoski KP and Peeva $E$. Raloxifene modulates estrogen-mediated $B$ cell autoreactivity in NZB/W F1 mice. J Rheumatol. 2010; 37:1646-57. | Article | PubMed

165. Julkunen HA. Oral contraceptives in systemic lupus erythematosus: side-effects and influence on the activity of SLE. Scand I Rheumatol. 1991; 20:427-33. | Article | PubMed

166. Counihan KA, Vertosick FT and Kelly RH. Anti-estrogen antibodies in systemic lupus erythematosus: a quantitative evaluation of serum levels. Immunol Invest. 1991; 20:317-31. | Article | PubMed

167. Sturgess AD, Evans DT, Mackay IR and Riglar A. Effects of the oestrogen antagonist tamoxifen on disease indices in systemic lupus erythematosus. J Clin Lab Immunol. 1984; 13:11-4. | PubMed

168. Mok CC, To CH, Mak A and Ma KM. Raloxifene for postmenopausal women with systemic lupus erythematosus: a pilot randomized controlled study. Arthritis Rheum. 2005; 52:3997-4002. | Article | PubMed

169. Ronnblom L and Alm GV. Systemic lupus erythematosus and the type I interferon system. Arthritis Res Ther. 2003; 5:68-75. | Article | PubMed Abstract | PubMed Full Text

170. Li J, Wang X, Zhang F and Yin H. Toll-like receptors as therapeutic targets for autoimmune connective tissue diseases. Pharmacol Ther. 2013; 138:441-51. | Article | PubMed

\section{Citation:}

Jiang $W$ and Gilkeson G. Sex differences in monocytes and TLR4 associated immune responses; implications for systemic lupus erythematosus (SLE). J Immunother Appl. 2014; 1:1. http://dx.doi.org/10.7243/2055-2394-1-1 